\title{
Primerjava zadovoljstva zaposlenih s kakovostjo delovnega in življenjskega okolja
}

\author{
Peter Ferfoglia \\ Fakulteta za Uporabne Družbene Študije, Gregorčičeva 19, 5000 Nova Gorica, Slovenija \\ peter.ferfoglia@gmail.com \\ Mirko Markič* \\ Univerza na Primorskem, Fakulteta za management, Cankarjeva 5, 6000 Koper, Slovenija \\ mirko.markic@fm-kp.si
}

\begin{abstract}
Povzetek:
Raziskovalno vprašanje (RV): Kolikšna je primerljivost zadovoljstva zaposlenih z njihovim delovnim in življenjskim okoljem?

Namen: Opraviti teoretični pregled metod za preverjanje zadovoljstva zaposlenih v podjetju ter pripraviti in empirično testirati novo zasnovani pripomoček 'kompas' po metodi Life Design.

Metoda: Izvedli smo primerjalno analizo šestih orodij, metod in tehnik, med katerimi je bil tudi novi pripomoček 'kompas'. V empiričnem delu raziskave smo z analizo DEXi uporabili novo metodo ter rezultate $\mathrm{z}$ linearno regresijo matematično-grafično primerjali $\mathrm{s}$ podatki iz Evropske družboslovne raziskave.

Rezultati: S pripravo in uporabo novega pripomočka 'kompas' smo ugotovili, da lahko spremljamo organizacijsko klimo in zadovoljstvo zaposlenih z metodo Life Design. Dokazali smo, da s podatkovnim rudarjenjem lahko prepoznamo ključne dejavnike za ocenjevanje zadovoljstva $v$ življenjskem okolju, ki je primerljivo z zadovoljstvom zaposlenih.

Organizacija: Predstavili smo vidike in dejavnike, ki lahko menedžerjem pomagajo pri prepoznavi zadovoljstva zaposlenih v primerjavi z zadovoljstvom v njihovem življenjskem okolju.

Družba: Na podlagi ugotovitev smo predlagali nov pripomoček, s pomočjo katerega pripomoremo $\mathrm{k}$ večjemu osebnemu zadovoljstvu zaposlenih in njihovega okolja ter izboljšanje uspešnosti podjetja. Originalnost: $V$ teoretičnem delu smo na enem mestu opisali izbrana orodja, tehnike in metode za ugotavljanje kakovosti dela in življenja. Zasnovali smo konkretne predloge ter dokazali njihovo uporabnost za analiziranje kakovosti delovnega in življenjskega okolja.

Omejitve/nadaljnje raziskovanje: Predlagamo, da se preveri uporabnost spoznanj z dodatnimi intervjuji ter na večji populaciji podjetij in drugih ustanov.
\end{abstract}

Ključne besede: človeški viri, Design Thinking, dobro počutje, kakovost dela, kakovost življenja, Life Design, menedžment, organizacijska klima.

\section{Uvod}

Pomembnost preverjanja organizacijske klime ima vedno večji pomen, česar se v podjetjih in drugih ustanovah vse bolj zavedajo. $Z$ dobro organizacijsko klimo naj bi povečevali učinkovitost zaposlenih in poslovno uspešnost organizacije. Preverjanje organizacijske klime 
je aktivnost, ki se v podjetjih in drugih ustanovah opravlja zgolj občasno, ker ta aktivnost zahteva čas in energijo ter temeljite analize za pridobivanje informacij ter končnih izidov.

Organizacijsko klimo definiramo kot niz merljivih lastnosti zaposlenih z vplivom na njihovo motivacijo in okolje (Bitenc, 2015, str. 23), kot zaznavo organizacijske politike, prakse in postopkov (Reichers in Schneider, 1990, str. 39), dojemanje pogojev dela za izpolnjevanja življenjskih potreb (Neal, West in Patterson, 2000, str.5) in vzdušje v podjetju kot ga zaznavajo njeni člani in vpliva na njihovo vodenje (Burton, Lauridsen in Obel, 1999, str. 9).

V podjetjih in drugih ustanovah namenjajo človeškim virom vedno večjo pozornost (Cuttelè in Forastiere, 2019, str. 67). Z opravljanjem različnih raziskav si prizadevajo ugotavljati organizacijsko klimo, kar je zamudno in finančno zahtevno opravilo. Poleg ugotavljanja organizacijske klime, je potrebno preverjati tudi kako in kolikšen je vpliv počutja na delovnem mestu na preživeti čas izven dela, v domačem okolju, med prostim časom in razvedrilom ter drugimi aktivnostmi, ki niso povezane $\mathrm{z}$ delom in obratno. Zaradi te vzajemnosti je nujno redno preverjanje počutja zaposlenih $\mathrm{v}$ organizaciji in izven nje.

Opravili smo pregled domače in tuje strokovne literature z namenom primerjalne analize orodij, metod in tehnik za zadovoljstvo zaposlenih. Iz metode Life Design, smo razvili nov pripomoček 'kompas' in ga primerjali z izbranimi drugimi orodji, metodami in tehnikami ter jih prikazali $\mathrm{v}$ sklepni tabeli. V izbranem podjetju smo nov pripomoček testirali in z njegovo pomočjo ugotavljali trenutno stanje organizacijske klime ter zadovoljstva. Posebej smo bili pozorni na uporabnost metode Design Thinking za kreativni organizacijski razvoj, ki z uporabo grafičnovizualnih pripomočkov postavlja $\mathrm{v}$ ospredje zadovoljstvo kupcev (Kelley, 2019, str. 4). Uporaba metode Design Thinking zahteva elastičnost in prilagodljivost glede na trenutne potrebe, kar je potrebno upoštevati ob njeni aplikaciji na področju menedžmenta človeških virov. Ugotovljeno zadovoljstvo zaposlenih $\mathrm{v}$ izbranem podjetju smo nato primerjali $\mathrm{s}$ kakovostjo življenja. Informacije o kakovosti življenja smo pridobili iz prosto dostopnih podatkov Evropske družboslovne raziskave (European Social Survey, v nadaljevanju: ESS). Dokazali smo praktično uporabnost pripomočka 'kompas', ki smo ga nadgradili z metodo hitrega cikličnega ravnanja in matematično-grafično primerljivostjo zadovoljstva zaposlenih $\mathrm{s}$ kakovostjo dela in kakovostjo življenja (Ferfoglia, 2020, str. 65).

\section{Teoretična izhodišča}

Organizacijska klima predstavlja skupek soodvisnih dojemanj, povezanih $\mathrm{z}$ delovno in organizacijsko realnostjo. Predstavlja način, kako udeleženci, ki ji pripadajo, dojemajo in razlagajo organizacijo in njene značilnosti. Kakovost organizacijske klime vpliva na poslovno uspešnost podjetja in druge ustanove ter na vedenje zaposlenih sodelavcev. Poznavanje organizacijske klime pomeni ugotavljanje stanja v organizaciji, kot ga zaznavajo tisti, ki so njen sestavni del (Fontanelli, 2013, str. 33), (Schneider, Ehrhart in Macey, 2012, str. 361).

Analiza organizacijske klime v podjetju ali drugi ustanovi je koristno orodje, pripomoček in tehnika za razumevanje poti, ki naj bi ji sledili v organizaciji. Z njeno pomočjo se seznanimo 
o organizacijski opredeljivosti in prepoznavnosti, da načrtujemo ter načrtujemo novosti $\mathrm{v}$ politiki in strategiji organizacije. Koristna je pri spoznanju težav in snovanju ukrepov za izboljšanje. Z njeno pomočjo razširjamo smotre in cilje organizacije. Ob prepoznanju vrzeli med njenimi različnimi dojemanji, in s pomočjo ugotavljanja organizacijske klime, spremljamo učinke ter spremembe organizaciji koristnih preobrazb (Daprà, 2020, str. 17). Ob njenem merjenju naj bi sodelavci občutili in prepoznali sami sebe kot odločilni dejavnik v organizaciji, da bodo slišani in upoštevani (Medeot, 2005, str. 75).

Posameznik potrebuje osebno samouveljavljanje $\mathrm{z}$ aktivnim delom in $\mathrm{z}$ ustvarjalnostjo (Mihelič, Lipičnik in Tekavčič, 2010, str. 31) in s tem skupnosti nudi svoj prispevek in obudi ter ohrani občutek pripadnosti v spoštovanju dela vsakogar in vzajemnega zaupanja. V delu uživa tudi, ker ustvarja koristi za družbo. Goi $(2008$, str. 14, 198) ugotavlja, da se v organizaciji ustvari dobro počutje ko je delovno mesto zdravo, udobno in prijazno, ko so cilji SMART (specifični, merljivi, atraktivni-dosegljivi, realni in terminsko določeni) in se v njih priznava prispevek ter veščine posameznika. Upoštevajo naj se značilnosti virov in njihova izkoriščenost, odkrito sodelovanje in hitro odločanje, plača glede na pristojnosti in odgovornosti, odprtost v zunanje družbeno okolje s tehnološkimi in kulturnimi inovacijami. Avtor ob tem navaja tudi kazalnike zadovoljstva in kazalnike nezadovoljstva (Tabela 1):

Tabela 1. Kazalniki zadovoljstva / nezadovoljstva

\begin{tabular}{ll}
\hline Kazalniki zadovoljstva & Kazalniki nezadovoljstva \\
\hline Zadovoljstvo do organizacije, & Nestrpnost do dela, \\
želja po angažiranju & odsotnost z dela, \\
občutek pripadnosti timu, & nezanimanje za delo, \\
visoka zavzetost, & želja po menjavi službe, \\
visoka udeležba, & agresivnost in živčnost, \\
spoštovanje organizacijskih vrednot, & psihosomatske motnje, \\
spremembe negativnih pogojev, & občutek ne-manj-vrednosti, \\
dojemanje uspešnosti organizacije, & formalno spoštovanje pravil, \\
pomembnost osebnih odnosov, & hladnost v odnosih, \\
pozitivna slika do poslovodstva. & negativna slika do poslovodstva. \\
\hline
\end{tabular}

Povzeto in prirejeno iz Clima aziendale e gestione delle risorse umane: 270 fattori per analizzare, interpretare, capire e migliorare la qualità del lavoro. (str. 20), po A. Goi, 2008, Milano: Franco Angeli s.r.l. Tools.

Kakovost življenja je odvisna od kakovosti naših odnosov (Burnett in Evans, 2020, str. 21). Izidi iz raziskave o tem, kateri dejavniki so ključni za srečno življenje in dolgoživost, kažejo na to, da sta to odnosa 'koga imaš rad' in 'kdo te ima rad' (Vaillant, 2012, str. 257-260). Izhajajoč iz celostne vizije posameznika kot enota duha in telesa, intro-ekstra vertiranost, subjektivnostobjektivnost in stalno srečanje s svetom je to, kar je filozof Buber imenoval kot osnovni dejavnik tega, kar veže dve osebi (Milan, 2000, str. 56-57). Gre za zmožnost srečevanja in obvladovanja nekega osebnega eksistencialnega prostora tako, da smo na meji stika z drugo osebo, ne da bi vanjo skušali vdreti. Takšno srečanje nas vodi do popolnega spoštovanja 
občutkov obupa, ljubezni, duhovnosti, jeze, veselja, občutljivosti ipd. To je potreba razpoznati prisotnost bližnjega, prepoznavanje njegove vrednosti kot posameznika in subjekta, potrjevanje njegovega potenciala, empatično dojemanje njegovih izkušenj, ne da bi se v njem preslikovali (Clarkson, 2010, str. 9). V odnosu si zaželimo celovitost in polnost, občutek zavedati se, kdo smo in kako izražamo in uresničujemo svoj potencial (Salonia, 2011, str. 39-43).

Bockerman in Ilmakunnas (2012, str. 244-262) ugotavljata, da povečanje zadovoljstva z delovnim mestom, poveča dodano vrednost na opravljeno uro pri proizvajanju za $6,6 \%$. V raziskavi nista uporabila le ocenjevanje spremenljivk, ki obravnavajo endogenost zadovoljstva z delom in presečne korelacije (Judge, Thoresen, Bono in Patton, 2001, str. 376) ampak tudi različne metode, ki sta jih uvedla Olley in Pakes (Olley in Pakes, 1992, str. 1263) za razreševanje sočasnosti zadovoljstva na delovnem mestu in splošno uspešnostjo.

Pomemben korak k inovativnosti razvojnega procesa je predstavljala uvedba metode Design Thinking (nekateri prevajajo to kot 'oblikovalsko razmišljanje'), kreativna metoda za menedžment $\mathrm{v}$ podjetjih in drugih ustanovah. V ospredju je človek in njegove potrebe, ki so vključene v oblikovalsko orodje s pozornostjo na zmogljivost tehnologije in zahtev za poslovno uspešnost (Brown, 2020, str. 2). Metoda Design Thinking je pripomoček v katerem se uporablja grafične pripomočke ter opredeljena kot kulturna in inovativna - dinamična miselnost razvoja in proces ustvarjanja proizvodov, ki temeljijo na obsežnih raziskavah ter iterativnem oblikovanju prototipov. To naj ne bi bila zgolj 'metoda', ampak postaja kulturna opredelitev in vizija v kateri bistvena stranica trikotnika 'poslovanje-ljudje-tehnologija' ni več 'poslovanje' ampak 'ljudje' (Kemkpens, 2016, str. 19).

Iz metode Design Thinkinga, orodja za ustvarjalni podjetniški razvoj (Kelley, 2019, str. 37), sta Burnett in Evans razvila metodo Life Design, s pomočjo katere naj bi posamezniku pomagali doseči pravo zaposlitev oziroma to, kar naj bi v življenju z veseljem opravljal. Če posameznik opravlja to kar počne z veseljem, ob delu uživa. Ta užitek mu bo prinašal zadovoljiva finančna nadomestila ob uravnoteženosti dejavnika službe-družina in za seboj bo zapustil trajne učinke (Burnett in Evans, 2018, str. 41). Na splošno je mogoče povzeti metodo Life Design kot o tehniki za zadovoljevanje osnovnih človeških potreb. Sledenje načelom zadovoljevanja osnovnih človeških potreb iz vidika kakovost dela in kakovost življenja je predstavljalo eno izmed najpomembnejših predpostavk za nastajanje in uresničevanje našega namena.

Na podlagi ugotovitev iz predhodnih teoretičnih spoznanj smo formirali naslednje hipoteze:

- H1: Z metodo Life Design prepoznamo in sledimo organizacijski klimi ter zadovoljstvu zaposlenih.

- H2: Računalniška podpora pri odločanju pomaga pri ukrepih za izboljšanje organizacijske klime v izbranem podjetju.

- H3: S podatkovnim rudarjenjem prepoznamo ključne dejavnike za ocenjevanje zadovoljstva z delovnim in življenjskim okoljem. 
- H4: Zadovoljstvo zaposlenih je primerljivo z zadovoljstvom prebivalcev v življenjskem okolju.

\section{Metoda}

Raziskavo sta sestavljala teoretični (proučevanje strokovne literature) in empirični (anketiranje in analiziranje podatkov) del, kar prikazujemo na Sliki 1.

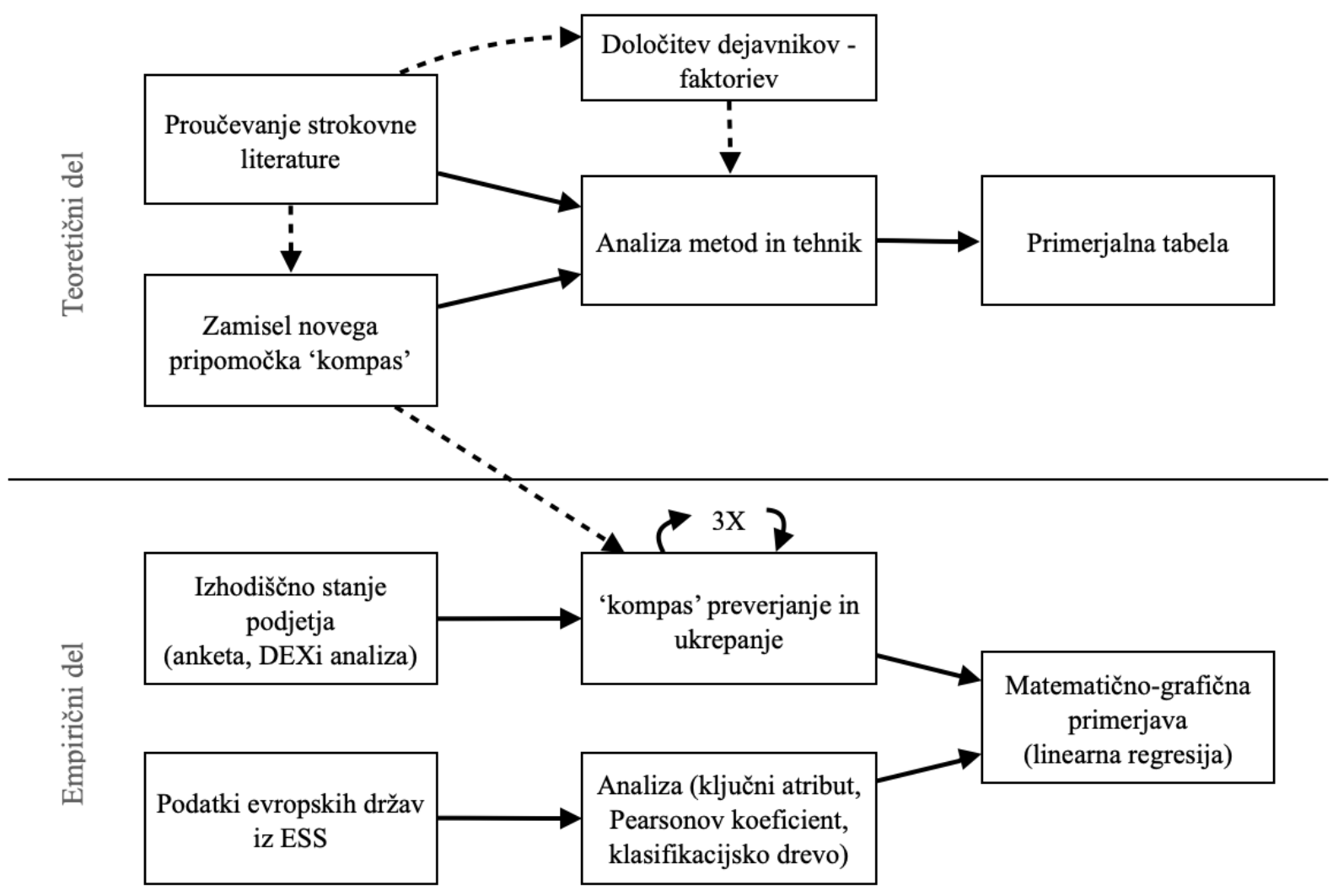

Slika 1. Model raziskave

Teoretični del naloge je temeljil na zbiranju in proučevanju domače ter tuje strokovne literature s področja menedžmenta, kakovosti dela in kakovosti življenja ter orodij, metod in tehnik za zadovoljstvo zaposlenih. Literaturo smo črpali iz knjig, monografskih zbirk, spletnih strani in znanstvenih člankov ter revij (predvsem iz Google Scholar, Academia.edu, Researchgate.net). Pri tem smo uporabili metodo deskripcije (opis pojmov in konceptov), kompilacije (povzetki in teoretična stališča) in sinteze (ugotovitve iz prakse in teorije) (Zelenika, 2000, str. 325-338). S kvalitativno analizo zbrane dokumentacije smo določili dejavnike (glej Faktorji iz Tabele 2) in primerjali izbrane metode: slovenski SiOK in Zlata Nit, Q12 ter skupek metod imenovan AZRM - akademsko znanstvenoraziskovalne metode. V primerjalno tabelo smo vključili metodo STAT (uporabnost prosto dostopnih statističnih podatkovnih baz, kot ESS in SiStat) in prirejeno uporabo metode Life Design za preverjanje organizacijske klime in zadovoljstva posameznikov z anketiranjem na naslednjih štirih ključnih področjih: zdravja, dela, igre in ljubezni. 
$\mathrm{Z}$ raziskovanjem smo ugotavljali teoretično uporabnost osnov iz metode Life Design in metode Design Thinking ter zasnovali nov pripomoček 'kompas', ki smo uporabili pri empiričnem preverjanju v izbranem podjetju. Poleg štirih ključnih področij (zdravje, delo, igra in ljubezen) naj bi zaposleni v pripomočku 'kompas' s skiciranjem dveh smeri prikazali koliko zaznavajo, da gredo v podjetju v pravo smer in koliko zaznavajo, da gre njegovo življenje (v primerjavi s smerjo podjetja) v pravo smer.

$\mathrm{V}$ empiričnem delu raziskave smo $\mathrm{v}$ srednje velikem slovenskem podjetju uporabili kvantitativni pristop, kot ga opisujejo Easterby-Smith, Thorpe in Lowe (2007, str. 163-169). Populacijo in vzorec nam je predstavljalo 32 zaposlenih sodelavcev. Z uvodnim anketiranjem smo ugotovili izhodiščno stanje $\mathrm{v}$ podjetja in preverili štiri vsebinske dele: komunikacija $\mathrm{v}$ podjetju (vodstvo - sodelavci, sodelavci - sodelavci, zaposleni - drugi, razreševanje konfliktov), prostost v podjetju (priznanje zmogljivosti in uspehov, operativna svoboda in vsiljevanje, raven konfliktnosti, prostost $\mathrm{v}$ družini kot pozornost podjetja na družinske potrebe), rast (odnosi, izobraževanje, menedžment znanja) in določanje ciljev (vrednotenje proizvodov podjetja, pozornost na stranke, osebne vrednote, vrednote podjetja, znanje in metode $\mathrm{v}$ upravljanju ter menedžmentu, podjetniško okolje).

Rezultate smo obdelali in opravili analizo s pomočjo metode DEX z aplikacijo DEXi za podporo pri odločanju in analizo več parametrskih kvalitativnih (simboličnih) parametrov (diskretni parametri) (Bohanec, 2020, str. 3).

Po testnem poskusu smo še tri krat (enkrat vsak mesec) izvedli anketiranje z novo zasnovanim pripomočkom 'kompas'. V obdobju poteka analiziranja smo se po potrebi bolj poglobljeno spoznavali s težavami anketiranih s pomočjo osebnih razgovorov (kvalitativni pristop) in jih poizkusili sprotno razreševati z izboljševalnimi aktivnostmi (skupinsko in osebno).

Primer skupinske težave anketiranih je bilo npr. spoznanje in priznavanje kompetenc vodjem podjetja. $Z$ anonimnim vprašalnikom odprtega tipa smo povabili vse zaposlene, naj nam navedejo najpomembnejše komunikacijske, vodstvene in tehnične kompetence za vodjo vsake organizacijske enote. Analizo podatkov smo opravili s tekstovnim rudarjenjem s pomočjo aplikacije OntoGen za aktivno učenje in gradnjo ontologij (Podpečan, 2019, str. 4-7). Potrebe posameznikov smo ugotavljali z intervjuji, kjer smo preverjali tako relacijsko-odnosno kot individualno razsežnost ter opazovali lastnosti medčloveških odnosov v podjetju.

Drugi del empirične analize smo opravili s pomočjo analize statističnih prosto dostopnih ESS podatkov od leta 2002 do leta 2016 (ESS, 2020, str. 9) iz šestih držav, Finske, Francije, Nemčije, Slovenije, Španije, Velike Britanije, za skupnih 98.635 instanc, s podatkovnim rudarjenjem in uporabo WEKA programa (Weka, 2020). Iz približno tisoč spremenljivk smo obdržali 197 uporabnih in iz teh izbrali ključno spremenljivko 'nivo sreče' ('happy': 'Glede na vse, koliko se počutite srečni?'). Uporabili smo algoritem CfsSubsetEval, da smo razkrili najbolj signifikantne spremenljivke, s funkcijo CorrelationAttributeEval smo poiskali Pearsonov koeficient korelacije na glavno spremenljivko 'happy', s katero smo preverili tudi uporabnost 
21 Schwartzovih atributov (Schwartz, 2003, str. 284-286). Za izgradnjo klasifikacijskega drevesa smo uporabili metodo $J 48$ in preverili uporabnost $\mathrm{z}$ apriorno verjetnostjo večinskega razreda (enačba 1) (Lavrač, 2019) (Bosnić, 2019). Z uporabo algoritma NaiveBayes (metode Naivnega Bayesa) smo potrjevali uporabnost končnih izbranih spremenljivk.

$$
p\left(c_{j}\right)=\frac{n\left(c_{j}\right)+1}{N+k}
$$

$\mathrm{V}$ zadnjem delu empirične raziskave smo podatke in trend zadovoljstva zaposlenih v podjetju utežili in prilagodili za primerjavo s podatki, ki smo jih prikazali s ciljno spremenljivko 'happy' iz prosto dostopnih podatkov ESS. Odvisnost med dvema spremenljivkama smo ugotavljali z linearno regresijsko premico (enačba 2) (Impedovo, 2006, str. 1-27).

$$
S(a, b):=\sum_{i=1}^{n}\left(k x_{i}+n-y_{i}\right)^{2}
$$

\section{Rezultati in razprava}

Ob pregledu dosedanjih raziskav smo ugotovili, da se avtorji prevladujoče ukvarjajo z analizo organizacijske klime v enem samem podjetju ali ustanovi. Zgolj nekaj raziskovalcev (Kozlovič, Lončar in Lovenjak) je opravilo primerjalno analizo izbranih vprašalnikov za merjenje organizacijske klime. Pri primerjavi slovenskih in tujih orodij, metod in tehnik za merjenje organizacijske klime, so izpostavile Pogačnikovo 'Lestvico Delovnega Zadovoljstva' kot najbolj primerno in psihometrično utemeljeno (Kozlovič, Lončar in Lovenjak, 2013, str.23). Podobno utemeljitev ustreznosti, popolnosti in psihometrične utemeljenosti so dali Van Saane, Sluiter, Verbeek in Frings-Dresen (Saane, Sluiter, Verbeek in Frings-Dresen, 2003, str. 191200) in Franci (Franci, 2012) za vprašalnik MJS - Measure of Job Satisfaction. Pri oblikovanju vprašalnika smo se oprli tudi na ugotovitve iz dela Moretti in Markič (Moretti in Markič, 2017, str. 77-90), da so zadovoljstvo zaposlenih, organizacijska klima in organizacijska kultura trije konstrukti, ki so soodvisni.

V tabeli 2 prikazujemo pregled dejavnikov za merjenje zadovoljstva zaposlenih, splošni pogled nad uvodnim raziskovalnim delom analiziranih izbranih orodij, metod in tehnik. Posebno pozornost smo namenili primerljivosti, periodičnosti in količini vprašanj za pogosta anketiranja izbrane populacije. Orodja, metode in tehnike naj ne bi bile časovno predolge, naj bi bile hitro odzivne in naj bi odražale trenutno družbeno okolje.

Ocenjena vrednotenja smo opravili s pomočjo 5-stopenske lestvice, od -2 (najbolj negativna) do +2 (najvišja pozitivna ocena) in so izid analize SWOT (slabosti in prednost ter izzivi in nevarnosti), ki smo jo opravili za vsako metodo. 
Tabela 2. Pregled dejavnikov za merjenje zadovoljstva zaposlenih

\begin{tabular}{lcccccc}
\hline Faktor & SiOK & ZNM & Q12 & AZRM & STAT & LDM \\
\hline Primerljivost podatkov & 1 & 1 & 1 & 1 & 2 & 1 \\
Kvantitativnost podatkov & 1 & 1 & 1 & 1 & 2 & 1 \\
Periodičnost podatkov & 1 & 1 & 1 & 2 & 1 & 2 \\
Dostopnost baze podatkov & 0 & 0 & 0 & 0 & 1 & 0 \\
Za podjetja & 2 & 2 & 2 & 2 & 0 & 2 \\
Za javne ustanove & 0 & 1 & 1 & 2 & 0 & 2 \\
Družinska klima & 0 & 0 & 0 & 1 & 1 & 2 \\
Osebna nagnjenja & 0 & 0 & 0 & 1 & 1 & 2 \\
Periodična izvedljivost & 0 & 0 & 1 & 2 & 0 & 2 \\
Razširjenost metode & 0 & 0 & 2 & 0 & 2 & 0 \\
Standardizacija & 1 & 1 & 2 & 0 & 2 & 0 \\
Konkurenčnost izvajalcev & -2 & -2 & -2 & -1 & 0 & 0 \\
Začetni stroški & -1 & -1 & -1 & -2 & 0 & -1 \\
Redni stroški & -2 & -2 & -2 & 0 & 0 & -1 \\
Ekonomski učinek & 2 & 2 & 1 & 1 & 0 & 1 \\
\hline SKUPNO & $\mathbf{3}$ & $\mathbf{4}$ & $\mathbf{7}$ & $\mathbf{1 0}$ & $\mathbf{1 2}$ & $\mathbf{1 3}$ \\
\hline
\end{tabular}

Legenda. SiOK=metoda SiOK; ZNM=metoda Zlata nit: Q12 metoda Q12; AZRM=Akademsko znanstvenoraziskovalne metode; STAT=Prostodostopni statistični podatki; LDM=Prirejena metada iz Life Design

Ugotovili smo, da je anketiranje s pomočjo orodja SiOK za podjetja in druge ustanove najbolj koristno, podobno je tudi Zlata Nit, ki pa je nekoliko bolj usmerjena na potrebe človeka in je primerna tudi za ustanove. Metoda Q12 ima veliko razširjenost v uporabi in ustrezni standardiziranosti vprašanj, slabost so stroški izvedbe in manj poglabljanja $\mathrm{v}$ podrobnosti. Akademska znanstveno-raziskovalna orodja, v kolikor jih strokovnjaki ciljno pripravijo, so (ali lahko postanejo) zelo dobra izbira za izvedbo anketiranja. Prosto dostopni statistični podatki so poceni in usmerjeni k potrebam človeka. Zasnovani raziskovalni grafični pripomoček 'kompas' iz metode Life Design, je možno pogosto ponoviti, je ciljno usmerjen, enostaven in primerljiv med organizacijami. Sestavljala ga je poizvedba štirih postavk (delo, ljubezen, igra in zdravje) $\mathrm{v}$ dveh smereh (podjetje in življenje), ki so nam dale hiter pregled nad stanjem organizacijske klime v izbranem podjetju, kot tudi za vsakega posameznika.

Na ta način smo potrdili prvo hipotezo H1: Z uporabo metode Life Design lahko prepoznamo in sledimo organizacijski klimi in zadovoljstvu zaposlenih.

Pri empiričnem delu smo začetno analizo opravili z anketiranjem in analizo podatkov $\mathrm{z}$ uporabo računalniške podpore pri odločanju. Šlo je za preverjanje težko merljivih lastnosti, kjer imajo glavno vlogo psihologija, človeški občutki in čustva. Anonimna anketa nam je pomagala pri odločanju kateri bi bili najučinkovitejši ukrepi za izboljšanje stanja organizacijske klime (skupne strategije za izboljševalne ukrepe), zaradi anonimnosti in pomanjkanja možnosti identifikacije vsakega posameznika, pa nam ni pomagala pri sledenju posameznikov temveč le celotne skupnosti zaposlenih. 
Hipotezo H2 nismo potrdili, saj nam je bilo brezosebno začetno preverjanje le delno v pomoč za hitre ukrepe in izboljšanje stanja organizacijske klime v izbranem podjetju.

Z uporabo modificirane metode 'kompas' smo ugotovili zaznavanje zadovoljstva zaposlenih. Pri vrednostih od 1 do 5 (najvišja vrednost) smo novembra 2019 imeli za 'zdravje' 3,59, 'delo' 3,43, 'igra' 3,83 in 'ljubezen' 3,72. Januarja 2020 za 'zdravje' 3,72, 'delo' 3,79, 'igra' 3,86 in 'ljubezen' 3,83, končno pa februarja 2020 za 'zdravje' 3,81, 'delo' 4,00, 'igra' 3,93 in 'ljubezen' 3,85. Presenetljiv izid smo dobili ob analiziranju, koliko zaposlenih je občutilo, da njihovo življenje gre $\mathrm{v}$ eno smer, delo-podjetje pa v nasprotno. Začetne vrednosti niso bile naklonjene skupni poti, trend pa se je nenehno izboljševal in tako smo v treh mesecih prešli od 30,43\% zaposlenih, ki so občutili različno smer v prvem preverjanju, do 17,24 \% v drugem, do presenetljivo nizkih 3,13\% zadnjega preverjanja. Odklone s prave smeri in kolikšni so bili ti odkloni med smerjo življenja in dela prikazujemo z grafom (slika 2).

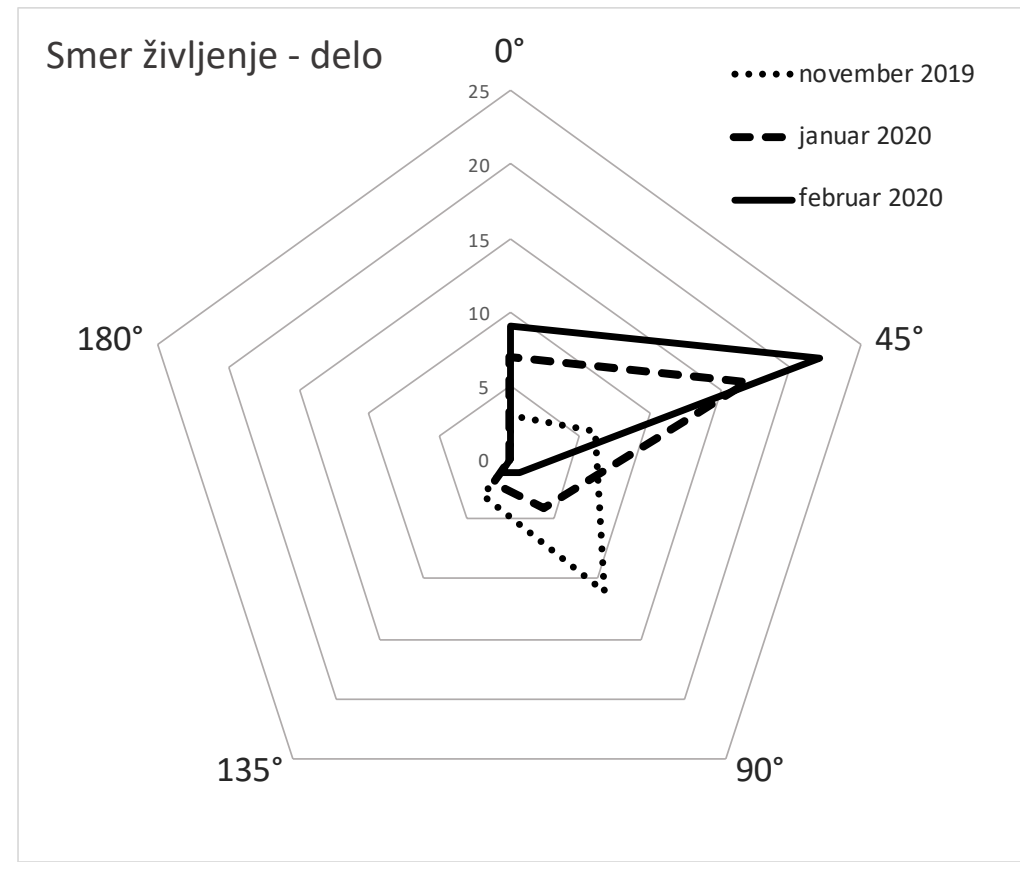

Slika 2. Grafični prikaz odklona življenje-delo

Pri naslednjem koraku, analizi statističnih prosto dostopnih podatkov, smo iskali spremenljivke, ki jih uporabljamo za odkrivanje zadovoljstva v domačem okolju. Iz vseh spremenljivk smo določili 197 uporabnih in končno eno, ki je bila naša glavna ciljna spremenljivka, 'nivo sreče' (ang. 'happy'). Z algoritmom CfsSubsetEval smo identificirali devet najbolj signifikativnih spremenljivk med katerimi izstopa 'stflife' (Koliko ste v celoti zadovoljni s svojim življenjem?), ki smo jo obdelali s CorrelationAttributeEval in dobili s Pearsonovim koeficientom najvišjo povezanost $(0,6894)$. Pri analizi z 21 Schwartzovimi atributi se je Pearsonov koeficient glavne spremenljivke 'happy' močno zmanjšal. Najvišjo vrednost je dobil 'iplylfr' (Pomembnost biti zvest prijateljem in se jim posvetiti) $(0,0235)$, kar smo opredelili kot neznatno povezanost med spremenljivkama. 
Za podatke iz Slovenije (10.914 instanc) smo sestavili klasifikacijsko drevo s pomočjo metode J48. Apriorna verjetnost je bila 26,04 \%, klasifikacijska točnost za 12 spremenljivk, ob rezanem drevesu (pruned) z najmanj 10 točnih klasifikacij je bila 45,81\%, za najmanj 20 točnih klasifikacij je bila 46,20 \%, za 50 točnih pa 46,32\%. Pri drevesu z devetimi spremenljivkami smo dobili za 10 točnih klasifikacij 45,31 \%, za 20 točnih 46,32 \%, za 50 točnih pa 46,51\% klasifikacijsko točnost. Dokazali smo, da je klasifikacijsko drevo spremenljivk uporabno pri vseh primerih. $\mathrm{Z}$ uporabo algoritma NaiveBayes (metode Naivnega Bayesa) smo za podatke $\mathrm{z}$ devetimi spremenljivkami ugotovili klasifikacijsko točnost 47,92\%, za podatke z 12 spremenljivkami pa $41,47 \%$. Tudi ta test nam dokaže, da so spremenljivke uporabne za klasifikacijo. V tej analizi smo dobili apriorno vrednost večinskega razreda 52,24\%, klasifikacijsko točnost pa 79,75 \%, kar je za 27,51 \% boljši izid. Zgrajeno klasifikacijsko drevo prikazujemo na Sliki 3.

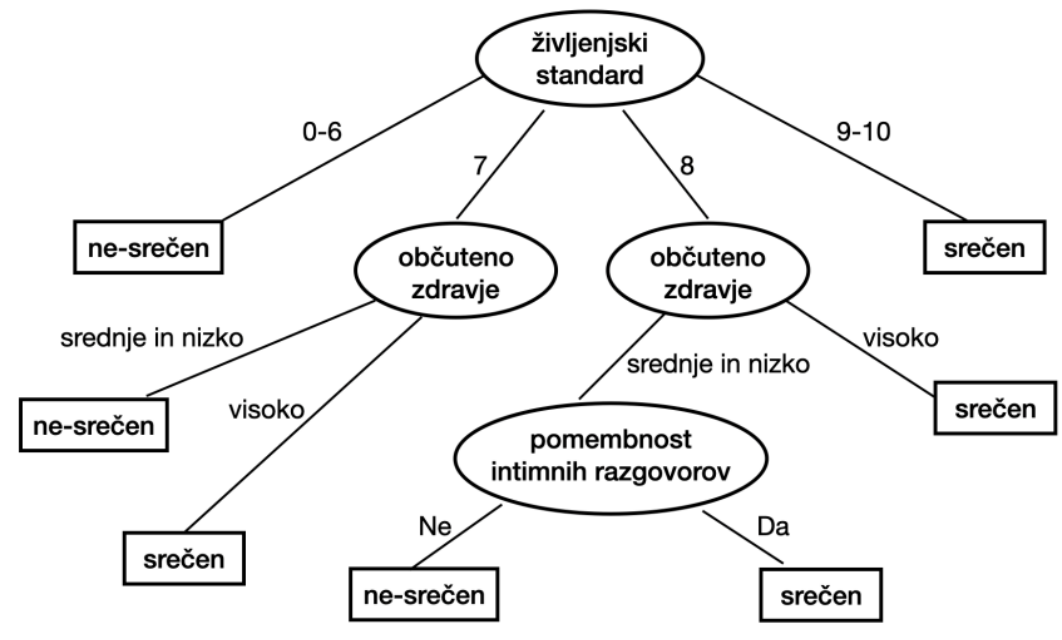

Slika 3. Klasifikacijsko drevo

Iz tega dela raziskave smo ugotovili primernost podatkovnega rudarjenja za iskanje ključnih dejavnikov zadovoljstva. Izkazala se je celovita uporabnost poglavitnih dejavnikov / ključnih besed, s pomočjo katerih smo pridobili objektivne rezultate ob veliki količini razpoložljivih osnovnih podatkov. Različica podatkovnega tekstovnega rudarjenja za analizo odprtih tekstov pri iskanju kompetenc vodij je najbolj uporabna za veliko število tekstovnih podatkov.

Hipotezo H3 smo potrdili, ker smo s podatkovnim rudarjenjem prepoznali ključne dejavnike za ocenjevanje zadovoljstva zaposlenih in zadovoljstva v življenjskem okolju.

Po ugotovitvi stanja zadovoljstva zaposlenih $\mathrm{v}$ izbranem podjetju smo dobljene podatke primerjali s podatki, ki nam jih je prikazovala ciljna spremenljivka 'happy'. Poiskali smo odvisnost (torej vplivnost) med dvema spremenljivkama z metodo iskanja linearne regresije. Preverjanje ravnotežja delo / življenje je tisti kazalnik, ki najbolj vpliva na zadovoljstvo zaposlenih (Rani, Kamalanbhan in Selvarana, 2011, str. 85-96). Pri $k$ (smerni koeficient) in $R^{2}$ (korelacijski faktor) smo za podjetje dobili sledeče prilagojene podatke: oktober 2019, $k=1,2648, R^{2}=0,0941$; januar 2020, $k=2,6646 R^{2}=0,6405$; februar 2020, $k=2,9091, R^{2}=0,6178$. 
Za podatke povprečnega zadovoljstva v življenjskem okolju (2002-2016) iz ESS pa naslednje: EU (zbrane države), $k=2,2456, R^{2}=0,6024$; Slovenija, $k=2,004, R^{2}=0,6208$. Grafična predstavitev nam lažje prikaže vrednosti in tendence zadovoljstva (slika 4):

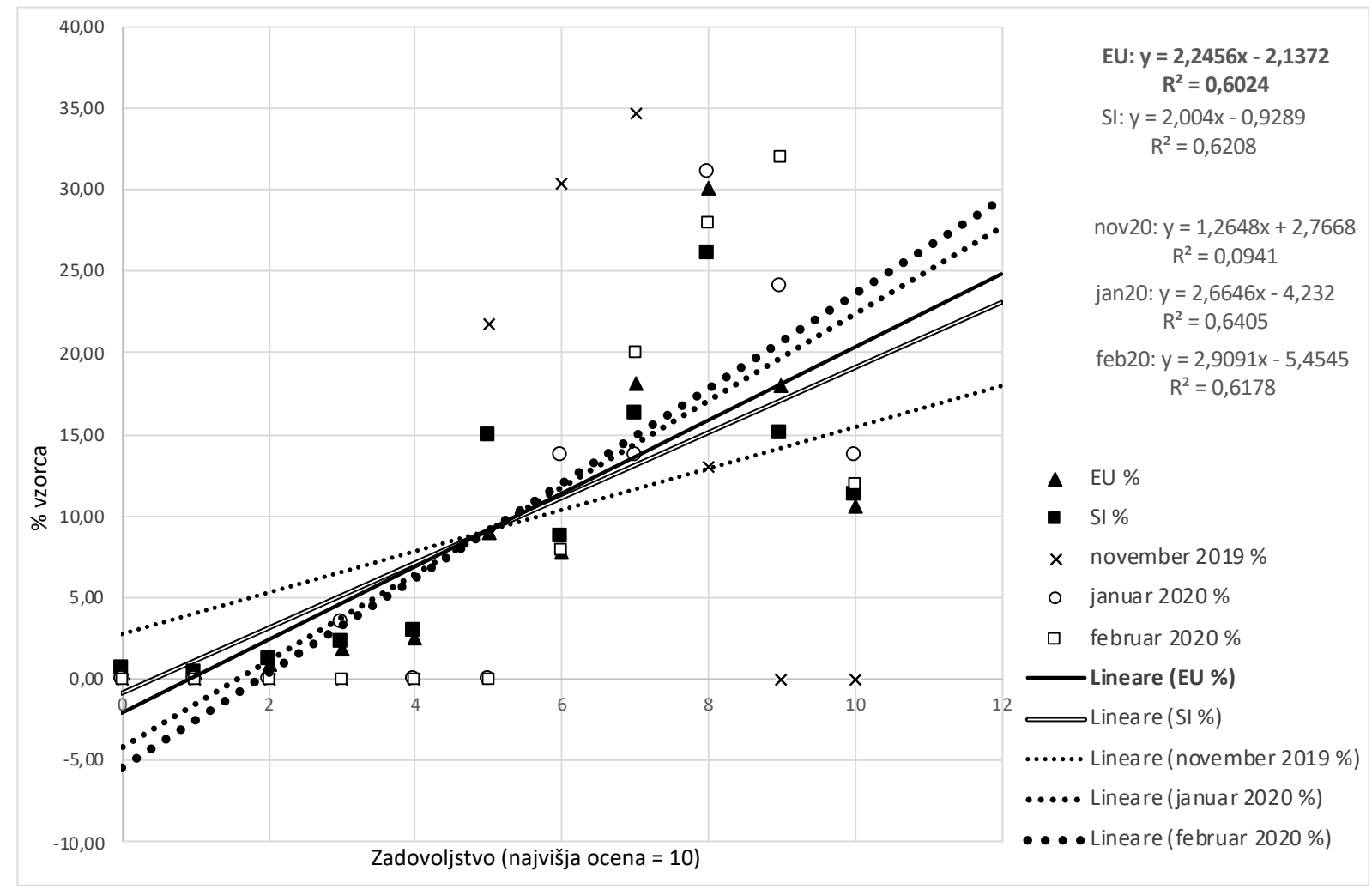

Slika 4. Občutek zadovoljstva v podjetju in življenjskem okolju

Uspešnost katere koli dejavnosti ali aktivnosti najbolje določimo, ko jo primerjamo z drugimi podobnimi in ko za te ugotovimo trend rasti ali upadanja. Z matematičnim postopkom smo parametra zadovoljstva zaposlenih in zadovoljstvo prebivalcev v življenjskem okolju, utežili in ju z linearno regresijo številčno in grafično primerjali ter dokazali njihovo soodvisnost.

Hipoteza H4 smo potrdili, ker je bilo zadovoljstvo zaposlenih primerljivo z zadovoljstvom prebivalcev v življenjskem okolju.

\section{Zaključek}

$\mathrm{V}$ teoretičnem delu raziskave smo ugotavljali prednosti in pomanjkljivosti pri uporabljenih vprašalnikih za preverjanje zadovoljstva posameznikov ter organizacijske klime. Ugotovili smo, da ti vprašalniki niso primerni za pogosto preverjanje in hitro odzivanje za korektivne ukrepe, kot je to možno s pomočjo metode Design Thinking. S pomočjo metode Life Designa je mogoče pripraviti nova in enostavna orodja, metode in tehnike za menedžment človeških virov. Na ta način nam je omogočeno, da lahko hitro in redno sledimo zadovoljstvu zaposlenih in preverjamo organizacijsko klimo vseh zaposlenih $\mathrm{v}$ podjetju in jo po potrebi hitro spreminjamo. Zasnovani pripomoček 'kompas', ki smo ga izdelali po načelih iz metode Life 
Design in metode Design Thinking, se je izkazal za koristnega, kar smo dokazali z empiričnim preverjanjem in praktičnim izboljšanjem organizacijske klime v izbranem podjetju.

$\mathrm{V}$ vsakem podjetju ali drugi ustanovi najbolje ocenimo svoje delovanje s primerjanjem z drugimi konkurenčnimi, od našega boljšimi podjetji, in z zadovoljstvom v družbenem okolju organizacije. Iz prosto dostopnih podatkov smo $\mathrm{z}$ uporabo podatkovnega rudarjenja in informacijsko-komunikacijske tehnologije razbrali zadovoljstvo $\mathrm{v}$ družbenem okolju in ponudili primerjalno podlago za izbrano podjetje. Z matematično-grafičnim primerjalnim postopkom in linearno regresijo smo potrdili soodvisnost kakovosti delovnega in življenjskega okolja ter uporabnost izbranih metod.

Podjetju smo predlagali redno spremljanje zadovoljstva $\mathrm{z}$ delom in življenjskim okoljem, s pomočjo uporabe hitrih orodij, metod in tehnik. Za boljšo objektivnost in hitrejšo izvedbo predlagamo uporabo podatkovnega rudarjenja. Zaznane težave naj bi v podjetju kar najhitreje začeli razreševati, ker so $\mathrm{v}$ podjetju najbolj vplivne. Poleg rednega ocenjevanja vodij predlagamo še intenzivnejše uvajanje timskega dela s prepoznanjem in uveljavitvijo vseh timskih vlog, kot jih predlaga Belbin (2010, str. 36-137) in Zakrajšek (2015). Na ta način bi podjetje nadgradili z novo dinamično vizijo v katerem bi vsak posameznik bolj zaživel v svoji edinstvenosti in povečal osebno zadovoljstvo, iznajdljivost in soudeležbo.

Teoretični prispevek k znanosti in stroki je v tem, da smo na enem mestu opisali izbrana orodja, tehnike in metode za ugotavljanje kakovosti dela in kakovosti življenja ter omogočili poglobljen in pregleden vpogled na izbrano tematiko. S pomočjo izdelane tabele o pregledu šestih metod, tehnik in orodij za merjenje petnajstih dejavnikov zadovoljstva zaposlenih smo jih strnili v enovit in pregleden prikaz. Izdelali smo nov pripomoček 'kompas', kar je izvirno delo in v takšni obliki ter načinu do zdaj še neevidentirano.

Empirični prispevek k znanosti in stroki se kaže v opravljeni analizi metod za raziskave vpliva zaposlenih na njihovo življenjsko okolje v izbranem podjetju. Prikazali smo, kako so po opravljenih aktivnostih z uporabljeno metodo zaposleni občutili, da smer, kamor gre podjetje, v katerem so zaposleni, je postalo bližje smeri, kamor teži njihovo osebno življenje. Ustvarila se je večja harmonija in povezanost potreb-ciljev podjetja in potreb-ciljev posameznikov. Izboljšanje občutka zadovoljstva smo grafično evidentirali in matematično dokazali kako sta se občutek zadovoljstva zaposlenih in organizacijska klima izboljšala, tudi primerjalno $\mathrm{z}$ vsesplošnim zadovoljstvom ljudi v Sloveniji in Evropski skupnosti. Za poslovodstvo je takšno primerjanje podatkov pomembno, saj tako lažje sledi in poveča učinkovitost človeških virov ter podatke primerja $\mathrm{z}$ dogajanjem $\mathrm{v}$ družbenem okolju.

V nadaljnjih raziskovanjih bi bilo smiselno preveriti uporabnost spoznanj z opravljanjem intervjujev z večjo populacijo podjetij, predvsem srednjih in velikih. Dodatna raziskovanja naj tudi potrdijo ali ovržejo, da je najbolj pomemben trend izboljšanja ali poslabšanja občutka posameznika, ki posledično vpliva na celotno skupnost in poslovno uspešnost podjetja ali druge ustanove. Kratko anketiranje je smiselno preveriti tudi $\mathrm{v}$ pridobitnih ali nepridobitnih 
dejavnostih $\mathrm{z}$ različnimi organizacijskimi modeli $\mathrm{v}$ drugih državah in $\mathrm{v}$ drugih kulturah. Možnost nadaljnjih raziskav je tudi v uporabi kvalitativnih znanstvenoraziskovalnih metod in primerljivosti z merljivimi (ekonomsko-finančnimi, organizacijsko-procesnimi) ter nemerljivimi (npr. ugled, trajnostni razvoj, družbena odgovornost ipd.) kazalniki uspešnosti organizacije.

\section{Reference}

1. Belbin, R. M. (2010). Management teams: Why they succeed or fail, 4rd ed. Routledge: Taylor \& Francis, 36-137.

2. Bitenc, P. (2015). Kaj je organizacijska klima. Pridobljeno iz OCR Svetovanje in raziskave: http://www.ocr.si/?p=22

3. Bockerman, P., \& Ilmakunnas, P. (2012). The Job Satisfaction-productivity Nexus: A Study using Matched Survey and Register Data. ILRReview, 2(65), 244-262. doi:10.1177/001979391206500203

4. Bohanec, M. (2020, 25. maj). DEXi: A Program for Multi-Attribute Decision Making. Pridobljeno na https://kt.ijs.si/MarkoBohanec/dexi.html

5. Bosnić, Z. (2019, 5. maja). Osnove Umetne Inteligence 2019/2020. Pridobljeno na ucilnica.fri.unilj.si: https://ucilnica.fri.uni-lj.si/pluginfile.php/67169/mod_label/intro/ P03\%20Rezanje\%20dreves\%2C\%20manjkajoči\%20atributi-6.pdf

6. Brown, T. (2020, 19. maja). Design Thinking Defined. Pridobljeno na Ideo Design Thinking: https://designthinking.ideo.com

7. Burnett, B., \& Evans, D. (2018). Designing your life: how to build a well-lived, joyful life. New York: Alfred A. Knopf.

8. Burnett, B., \& Evans, D. (2020). Designing your work life: how to thrive and change and find happiness at work. New York: Alfred A. Knopf, 21.

9. Burton, R. M., Lauridsen, J., \& Obel, B. (1999). Tension and Resistance to Change in Organizational Climate: Managerial Implications for a Fast Paced World. Durham: Duke Univeristy, 3-9.

10. Clarkson, P. (2010). Gestalt Counseling: Per una consulenza psicologica proattiva nella relazione d'aiuto (Gestalt Counseling in Action). Roma: SoveraEdizioni Edorado Giusti, 9.

11. Cutellè, L., \& Forastiere, N. (2019). Un'analisi empirica dei flussi di investimento internazionali nelle start-up europee. (Magistrsko delo). Torino: Politecnico di Torino, 67-74.

12. d.life. (2019, 21. marca). Stanford life design lab - Design your life. (Stanford Life Design Lab) Pridobljeno na lifedesignlab.stanford.edu: http://lifedesignlab.stanford.edu

13. Daprà, O. (2020, 1. junija). Analisi del Clima Aziendale. Pridobljeno na NuovaEra: https://www.nuova-era.it/analisi-del-clima-aziendale/

14. Easterby-Smith, M., Thorpe, R., \& Lowe, A. (2007). Raziskovanje v managementu. Koper: Univerza na Primorskem, 163-169.

15. ESS. (2020, 28. aprila). ESS Slovenija. Pridobljeno na European Social Survey: https://www.europeansocialsurvey.org/about/country/slovenia/

16. Ferfoglia, P. (2020). Izboljšave metod za raziskave vpliva zaposlenih na njihovo življenjsko okolje (Magistrsko delo). Nova Gorica: Univerza v Novi Gorici.

17. Fontanelli, P. (2013). Potere predittivo del Clima Aziendale nella misura del benessere organizzativo (Magistrsko delo). Pisa: Università di Pisa - Facoltà di medicina e chirurgia, 33-39.

18. Franci, A. (2012, 5. avgusta). La soddisfazione lavorativa del personale ospedaliero. Pridobljeno na www.unibs.it/sites/files/ricerca/allegati/Franci-Soddisfazione personale ospedaliero -PDF.pdf 
19. Goi, A. (2008). Clima aziendale e gestione delle risorse umane: 270 fattori per analizzare, interpretare, capire e migliorare la qualità del lavoro. Milano: Franco Angeli s.r.1., 198-208.

20. Impedovo, M. (2006). Regressione: un'ipotesi di percorso didattico. Progetto Alice, VII(19), 1-27.

21. Judge, T. A., Thoresen, C. J., Bono, J. E., \& Patton, G. K. (2001). The job satisfaction-job performance relationship: A quantitative and qualitative review. Psychological Bulletin, 3(127), 376-407. doi: 10.1037/0033-2909.127.3.376

22. Kelley, D. (2019, 10. julija). Design Thinking is a process for creative problem solving. Pridobljeno na ideou.com: https://www.ideou.com/pages/design-thinking

23. Kemkpens, O. (2016, 30. aprila). Doing the right things. Pridobljeno na Slideshare.net: https://www.slideshare.net/ServiceDesignLinz/keynote-oliver-kempkens-jam-2016-design-thinking

24. Kozlovič, S., Lončar, T., \& Lovenjak, I. (2013). Izbrani vprašalniki za uporabo na področju psihologije dela in organizacije: delovno zadovoljstvo. Ljubljana: Univerza v Ljubljani Filozofska fakulteta, 23.

25. Lavrač, N. (2019). Odkrivanje zakonitosti v podatkih - delovno gradivo. Nova Gorica: Poslovnotehniška fakulteta - Univerza v Novi Gorici.

26. Medeot, S. (2005). La conoscenza organizzativa: un approccio sistemico. (Magistrsko delo). Trieste: Facoltà di Lettere e fillosofia - Università di Trieste, 75-85.

27. Mihelič, K. K., Lipičnik, B., \& Tekavčič, M. (2010). Ethical Leadership. International Journal of Management \& Information Systems, 14(5), 31-42. doi.org/10.19030/ijmis.v14i5.11

28. Milan, G. (2000). Educare all'incontro: la pedagogia di Martin Buber. Vol.96 - Percorsi dell'educare. Città Nuova, 56-57.

29. Moretti, M., \& Markič, M. (2017). Organizacijska kultura in organizacijska klima. Koper: Založba Univerze na Primorskem, 77-90. doi.org/10.26493/978-961-7023-65-7

30. Neal, A., West, M., \& Patterson, M. (2000). An examination of interactions between organizational climate and human resource management practices in manufacturing organizations. Aston Business School Memo, No. RP 003, 5.

31. Olley, G. S., \& Pakes, A. (1992). The Dynamics of Productivity in the Telecommunications Equipment Industry. Econometrica - NBER Working Papers, 6(64), 1263-1297. Pridobljeno s http://www.jstor.org/stable/2171831

32. Podpečan, V. (2019). Upravljanje znanja: Analiza besedil s programom OntoGen - učno gradivo. Poslovno-tehniška Fakulteta - Univerza v Novi Gorici, 4-7.

33. Rani, S., Kamalanabhan, \& Selvarana, M. (2011). Work/Life balance reflections on Employee Statisfaction. Serbian Journal of Management, 1(6), 85-96. http://www.sjm06.com

34. Reichers, A. E., \& Schneider, B. (1990). Climate and Culture: An evolution of constructs. Organizational climate and culture, 5-39.

35. Saane, N. v., Sluiter, J., Verbeek, J. H., \& Frings-Dresen, M. H. (2003). Reliability and validity of instruments meaasuring job satisfaction - a systematic review. Occupational Medicine, 53(3), 53: 191-200. doi: 10.1093/occmed/kqg038

36. Salonia, G. (2011). Sulla Felicità e dintorni: tra corpo, parola e tempo. Trapani: Il Pozzo Di Giacobbe Ed, 39-43.

37. Schneider, B., Ehrhart, M. G., \& Macey, W. H. (2012). Organizational Climate and Culture. The Annual Review of Psychology, 361-388.

38. Schwartz, S. H. (2003). A Proposal for Measuring Value Orientations across Nations (Izv. Chapter 7). Jerusalem: The Hebrew Univeristy of Jerusalem, 284-286. 
39. Vaillant, G. E. (2012). Triumphs of experience: the men of the Harvard Grant Study. Cambridge, MA: The Belknap Press of Harvard University Press, 257-260. doi.org/10.1080/01924788.2014.966574

40. Weka. (2020, 15. decembra). Weka 3: Data mining Software in Java. Pridobljeno na ai.waikato.ac.nz: https://ai.waikato.ac.nz/weka/

41. Zakrajšek, T. (2015, 10. julija). Oblikovanje in vodenje učinkovitih timov: Belbinove timske vloge. Pridobljeno na psihologijadela.com: https://psihologijadela.com/2015/01/02/oblikovanje-invodenje-ucinkovitih-timov-belbinove-timske-vloge/

42. Zelenika, R. (2000). Metodologija i tehnologija izrade znanstvenog i stručnog djela, četvrto izdanje. Rijeka: Ekonomski Fakultet u Rijeci, 325-338.

Peter Ferfoglia je doktorski študent sociologije na FUDŠ Fakulteti za uporabne družbene študije v Novi Gorici. Delavno izkušnjo v podjetjih in šolstvu ter poglabljanje v upravljanju in vodenju človeških virov (GEMA Rim) izpopolnjuje z nadaljnjim študijem. Diplomiral in magistriral je kot gospodarski inženir na Poslovno-tehniški fakulteti Univerze v Novi Gorici, kjer je bil tudi učitelj asistent. Svetovalno in raziskovalno se posveča vodenju človeških virov ter učinkovitosti, uspešnosti in zadovoljstvu zaposlenih, z razreševanjem socioloških vprašanj in uporabo inovativnih metod ter računalniških tehnologij.

$* * *$

Mirko Markič je doktoriral na Fakulteti za organizacijske vede Univerze v Mariboru s področja organizacijskih ved na temo inoviranja. Po dvanajstih letih delovanja v gospodarstvu se je zaposlil na Fakulteti za menedžment Univerze na Primorskem. Je redni profesor za področje menedžmenta in znanstveni svetnik ter vodja ali član 17 raziskovalnih projektov in projektov z gospodarstvom. Njegova bibliografija obsega več kot 630 enot s področja upravnih in organizacijskih ved ter javnega zdravstva (varstvo pri delu).

$* * *$

\section{Abstract: \\ Comparing the Employee Satisfaction with the Quality of the Work and Living Environment}

Research Question (RQ): What is the comparability of employee satisfaction with their environment?

Purpose: The purpose is to perform a theoretical review of methods for checking the employee satisfaction in the company and prepare and empirically test a newly designed tool 'compass' according to the Life Design method.

Method: We performed a comparative analysis of 6 tools, methods, and techniques, including a new 'compass' tool. In the empirical part of the research we used a new method with DEXi analysis and compared the results with linear regression mathematically and graphically with the data from the ESS European Social Survey.

Results: With the preparation and use of the new 'compass' tool, we recognized that we can follow the organizational climate and employee satisfaction with the Life Design method. We have demonstrated that with data mining can identify key factors for assessing satisfaction in the living environment, which is numerically comparable to employee satisfaction.

Organization: We have presented aspects and elements that can help managers identify employee satisfaction versus satisfaction in their living environment.

Society: Based on the findings, we proposed a new tool that helps to increase personal satisfaction of employees and their environment and consequently improve the company's performance. Originality: In the theoretical part, we described in one place the selected tools, techniques and methods for determining the quality of work and life. We designed concrete proposals and proved their usefulness for analyzing the quality of the work and living environment. 
Revija za univerzalno odličnost / Journal of Universal Excellence

December 2020, leto / year 9, številka / number 4, str. / pp. 309-324.

Limitations / further research: We suggest that the applicability of the findings be checked with additional interviews ad on a larger population of companies and other institutions.

Keywords: Design Thinking, human resources, Life Design, management, organizational climate, quality of work, quality of life, well-being.

Copyright (c) Peter FERFOGLIA, Mirko MARKIČ

\section{(c) $\underset{\mathrm{EY}}{(\mathrm{SP}}$}

Creative Commons License

This work is licensed under a Creative Commons Attribution-ShareAlike 4.0 International License. 